\title{
Climatic controls on leaf litter decomposition across European forests and grasslands revealed by reciprocal litter transplantation experiments
}

\author{
Miguel Portillo-Estrada ${ }^{1,2}$, Mari Pihlatie ${ }^{3}$, Janne F. J. Korhonen ${ }^{3}$, Janne Levula ${ }^{3,4}$, Arnoud K. F. Frumau ${ }^{5}$, \\ Andreas Ibrom ${ }^{6}$, Jonas J. Lembrechts ${ }^{1}$, Lourdes Morillas ${ }^{7}$, László Horváth ${ }^{8}$, Stephanie K. Jones ${ }^{9,10}$, and \\ Ülo Niinemets ${ }^{2,11}$ \\ ${ }^{1}$ Centre of Excellence PLECO (Plant and Vegetation Ecology), Department of Biology, University of Antwerp, \\ Universiteitsplein 1, 2610 Wilrijk, Belgium \\ ${ }^{2}$ Department of Plant Physiology, Institute of Agricultural and Environmental Sciences, Estonian University of Life Sciences, \\ Kreutzwaldi 1, Tartu 51014, Estonia \\ ${ }^{3}$ Department of Physics, Division of Atmospheric Sciences, 00014 University of Helsinki, Helsinki, Finland \\ ${ }^{4}$ Hyytiälä forest station, Hyytiäläntie 124, 35500 Korkiakoski, Finland \\ ${ }^{5}$ ECN, Environmental Assessment group, P.O. Box 1, 1755 ZG, Petten, the Netherlands \\ ${ }^{6}$ Technical University Denmark, Department of Environmental Engineering, Centre for Ecosystem \& Environmental \\ Sustainability, Frederiksborgvej 399, Risø-Campus, 4000 Roskilde, Denmark \\ ${ }^{7}$ Department of Sciences for Nature and Environmental Resources, University of Sassari, Via Enrico de Nicola, no. 9, 07100, \\ Sassari, Italy \\ ${ }^{8}$ Hungarian Meteorological Service, P.O. Box 39, 1675 Budapest, Hungary \\ ${ }^{9}$ Scotland Rural College, King's Buildings, West Mains Road, Edinburgh EH9 3JG, UK \\ ${ }^{10}$ Centre for Ecology and Hydrology $(\mathrm{CEH})$, Bush Estate, Penicuik, Midlothian, EH26 0QB, UK \\ ${ }^{11}$ Estonian Academy of Sciences, Kohtu 6, 10130 Tallinn, Estonia \\ Correspondence to: Miguel Portillo-Estrada (miguel.portilloestrada@uantwerpen.be)
}

Received: 7 October 2015 - Published in Biogeosciences Discuss.: 11 November 2015

Revised: 29 February 2016 - Accepted: 7 March 2016 - Published: 16 March 2016

\begin{abstract}
Carbon (C) and nitrogen (N) cycling under future climate change is associated with large uncertainties in litter decomposition and the turnover of soil $\mathrm{C}$ and $\mathrm{N}$. In addition, future conditions (especially altered precipitation regimes and warming) are expected to result in changes in vegetation composition, and accordingly in litter species and chemical composition, but it is unclear how such changes could potentially alter litter decomposition. Litter transplantation experiments were carried out across six European sites (four forests and two grasslands) spanning a large geographical and climatic gradient $\left(5.6-11.4{ }^{\circ} \mathrm{C}\right.$ in annual temperature $511-878 \mathrm{~mm}$ in precipitation) to gain insight into the climatic controls on litter decomposition as well as the effect of litter origin and species.
\end{abstract}

The decomposition $k$ rates were overall higher in warmer and wetter sites than in colder and drier sites, and positively correlated with the litter total specific leaf area. Also, litter $\mathrm{N}$ content increased as less litter mass remained and decay went further.

Surprisingly, this study demonstrates that climatic controls on litter decomposition are quantitatively more important than species or site of origin. Cumulative climatic variables, precipitation, soil water content and air temperature (ignoring days with air temperatures below zero degrees Celsius), were appropriate to predict the litter remaining mass during decomposition $\left(M_{\mathrm{r}}\right) . M_{\mathrm{r}}$ and cumulative air temperature were found to be the best predictors for litter carbon and nitrogen remaining during the decomposition. Using mean annual air temperature, precipitation, soil water content and 
litter total specific leaf area as parameters we were able to predict the annual decomposition rate $(k)$ accurately.

\section{Introduction}

In non-fertilized ecosystems, such as most grasslands and forests, the nitrogen $(\mathrm{N})$ flux in litter is the dominant $\mathrm{N}$ input into the soil (Berg and McClaugherty, 2008). The total gross amount of $\mathrm{N}$ mineralized in the soil is a product of the total litter mass production rate, the litter decomposition rate and the litter $\mathrm{N}$ content. Site climatic characteristics strongly affect the litter decomposition rate by modifying conditions for decomposers to act and transform organic litter matter into forms readily usable for plants (Berg et al., 1993). When both nutrients and decomposable carbon sources are present, temperature and soil moisture within certain ranges catalyse litter decomposition by enhancing soil biota's activity (Berg and McClaugherty, 2014a). Therefore, sites with different precipitation regimes and air and soil temperatures can present different litter decomposition rates. Soil characteristics, soil moisture (Bradford et al., 2016) and its microbial abundance and composition (Allison et al., 2013), and the species-related characteristics of litter also play an important role in the decomposition. Leaf litter may vary greatly in the elemental composition (Berg and McClaugherty, 2008), content of toxic chemicals such as terpenoids and alkaloids that are synthesized to protect against herbivory but also inhibiting soil microbes (Ormeño et al., 2009), anatomical traits like leaf mass per area, and mechanical characteristics like leaf tensile strength (Cornelissen and Thompson, 1997), resistance to fracture (Wright and Illius, 1995), and leaf toughness (Gallardo and Merino, 1993).

Many efforts have been made to model the carbon (C) and $\mathrm{N}$ release from decomposing litter across different climates (Bonan et al., 2013; Liski et al., 2005; Zhang et al., 2010). Models are needed to predict future levels of soil $\mathrm{N}$ availability and turnover rate. The decomposition $k$ rate is likely positively correlated with mean annual precipitation and temperature (Zhang et al., 2008). Moreover, in Europe, climate change is expected to increase air temperature, and reduce precipitation in southern countries, while both temperature and precipitation are predicted to increase in northern countries (Jacob et al., 2014). Therefore, models accounting for the changes in litter decomposition are urgently needed in order to understand the $\mathrm{C}$ and $\mathrm{N}$ dynamics in changing climate.

In order to gain insight into future climate effects on litter decomposition the biological and climatic controls of the decomposition need to be solved. Measuring litter decomposition across climatic transects is a technique which allows one to quantify the response of litter decomposition traits in relation to the specific climatic variations along a transect (Johansson et al., 1995). On the other hand, to measure the effects of litter species or chemical composition on decomposition, one can compare the decomposition rates from litter with different characteristics in a specific climate (Gallardo and Merino, 1993). For this reason, accounting with litter from different climates is certainly beneficial for these types of experimental setups. This is because leaf litter of the same species which originated in different climates may have different chemical composition, specific leaf area, etc., thus adding more range of variability to the analysis. As an example, leaves with a small specific area can be expected to be physically tough in terms of resistance to penetration and therefore mass loss and decomposition rate (Cornelissen, 1996). In this article, we present a combination of both experimental approaches to study the effects of both the climatic and the litter substrate characteristics, on the decomposition process. We carried out litter transplantation experiments to study litter decomposition rates across forest and grassland ecosystems from warm temperate to boreal Europe, with the major aim to separate the biological and climatic controls on litter decomposition. The specific aims of the study were (1) to assess the actual leaf litter decomposition rates and the $\mathrm{C}$ and $\mathrm{N}$ amounts remaining in the litter, (2) to study these as a function of the climatic characteristics and litter species, and (3) to generate a simple data-based model to predict the litter mass and litter $\mathrm{C}$ and $\mathrm{N}$ contents remaining after increasing time steps of decomposition.

In order to assess the rapid changes in the first days of the decomposition, which is important with respect to mass loss of the litter (Berg and McClaugherty, 2014b), we performed an intensive litter bag sampling during the first month of decomposition at Hyytiälä. The existence of a first leaching phase within the first days of decomposition may in typical litterbag experiments pass unnoticed, although it could account for ca. $10 \%$ of accumulated mass loss according to Berg and McClaugherty (2014b).

The European continent includes a large range of ecosystems differing in mean annual temperatures and cumulative annual precipitation. We were especially interested in comparing temperate sites with northern sites, which would present seasons with mean air temperature below zero Celsius degrees, because we hypothesize that litter decomposition is slowed down by freezing temperatures and lack of liquid water. Therefore, one of our goals is to make the model valid for temperate and northern climates.

\section{Material and methods}

\subsection{Study sites}

The study was conducted at six sites of the NitroEurope Integrated project (2006-2011 - http://www.nitroeurope.eu/). The sites covered various climates and ecosystems representative of the European continent and were each dominated by a single tree or grass species. The forest sites are 
Hyytiälä in Finland (Korhonen et al., 2013; Portillo-Estrada et al., 2013), Männikjärve in Estonia (Carter et al., 2012; Portsmuth et al., 2005), Sorø in Denmark (Pilegaard et al., 2011), and Speulderbos in the Netherlands (Portillo-Estrada et al., 2013), while the grassland sites are Easter Bush in the UK (Jones et al., 2011) and Bugac in Hungary (Machon et al., 2015). The details of the sites are provided in Table 1.

\subsection{Experimental design and litter collection}

We used the litterbag method (Bocock and Gilbert, 1957) and carried out reciprocal litter transplantation experiments to study the decomposition process from two perspectives: as an effect of species-related litter characteristics and as an effect of environmental conditions in the site of decomposition. Foliage litter produced by the dominant species of each site was shipped to all other similar ecosystem sites for decomposition under a different environmental condition to the original. In short, the litter samples were let to decompose at each site and samples were collected at regular intervals over a period of 1 year, after which the litter mass loss and $\mathrm{C}$ and $\mathrm{N}$ contents were analysed.

At the forest sites dominated by evergreen conifers (Hyytiälä, Männikjärve and Speulderbos), the senescent litter material was collected in litter traps placed above the forest floor and harvested once every month throughout the year 2008. At the deciduous forest site Sorø, the litter collection was done analogously, but only during the litterfall period between September and November 2008. At the grassland sites, current-year grass litter was harvested in late autumn by clipping the dead leaves at the base. In all cases, the litter was air-dried at room temperature and mixed every 2 days to avoid the onset of decomposition of non-aerated wet litter. Once the constant mass was reached, the litter was stored in air-tight bags until the start of the experiment.

All the litter collected was shipped to the same lab (Estonian University of Life Sciences) where the litter corresponding to leaves and needles was separated from the other litter fractions (e.g. cones, bark, twigs, etc.). All the leaf litter belonging to the same site was mixed together to create a standard mix of litter per site. This was done to avoid a bias in the decomposition rates due to temporal differences in litter $\mathrm{C}$ and $\mathrm{N}$ contents occurring throughout the year for conifers as showed by Portillo-Estrada et al. (2013) in Hyytiälä and Speulderbos conifer forests, and during the litter fall period for the deciduous species (Niinemets and Tamm, 2005). Moreover, mixing the litter collected from different litter traps of a site minimized the potential spatial differences in leaf anatomy (e.g. specific leaf area) occurring within a site.

Flat-shaped litter bags, made out of nylon screen $(1 \mathrm{~mm}$ mesh size, $15 \times 15 \mathrm{~cm}$ ), were filled with $5.5 \pm 0.01 \mathrm{~g}$ of airdried $\left(48 \mathrm{~h}\right.$ oven-drying at $\left.60^{\circ} \mathrm{C}\right)$ leaf material. The mesh size was considered small enough to prevent biomass loss through the mesh (for the conifer Douglas fir (Pseudotsuga menziesii) litter bags, a double layer of tissue was used to minimize the risk of losing leaf needles through the mesh), yet large enough to permit aerobic activity and entry of small soil animals (though excluding earthworms). A colour label was inserted in the litter bags to identify their original content (plant species and site origin) during the decomposition.

\subsection{Litter transplantation and decomposition}

Leaf litter from the four forest sites was shipped to all four forest sites for decomposition, and leaf litter from the grassland sites was sent to the two grassland sites. Altogether, a total of 288 tree litter bags were used for the decomposition experiments at forest sites.

- Forest sites: decomposing litter was sampled at five sampling times throughout the year. At each date, three replicate bags with litter from each site of origin (four forest sites) were collected at each site of destination $(5 \times 3 \times 4 \times 4=240$ litter bags $)$. Additionally, in Hyytiälä, three replicate litter bags were collected at four sampling times during the first month of decomposition, $(4 \times 3 \times 1 \times 4=48$ litter bags $)$.

- Grasslands: for the grass litter, 60 litter bags were prepared, corresponding to five sampling times during the year, three replicate litter bags per litter origin and two grassland sites were collected $(5 \times 3 \times 2 \times 2=60$ litter bags).

Immediately before installing the litter bags at the sites, the litter bags were moistened by spraying them with deionized water. After moistening, the bags were placed on the topsoil for decomposition. Each bag was fastened to a stainless steel or PVC stick with a nylon thread. The stick was pushed into the soil, in order to keep the bags in place. At each site, the litter bags were installed in the autumn at a representative day at or close to peak litterfall for forest sites and peak leaf die-off for grassland sites (see Table 1 for dates). Thus, the decomposition period of all the replicate litter bags within a site begun on the same date.

The mass remaining after the specified periods of decomposition was measured by randomly harvesting three replicate litter bags of each litter type of the same origin, later, the mass of the three replicates was averaged. The litter bags were collected on days 2, 5, 9 and 16 after the start of the decomposition treatment in Hyytiälä. In all sites, the bags were also collected approximately in 1, 2, 3, 6 and 12 months after the start. The litter bags were transported to the lab, where the remaining litter mass was oven-dried at $60^{\circ} \mathrm{C}$ for $48 \mathrm{~h}$ and weighed. The dried litter samples were then sent to the laboratory at the Estonian University of Life Sciences where the samples were post-processed and analysed for $\mathrm{C}$ and $\mathrm{N}$ content and leaf area. 
Table 1. Characteristics of the forest and grassland study sites.

\begin{tabular}{|c|c|c|c|c|c|c|}
\hline Site description & Hyytiälä & Männikjärve & Sorø & Speulderbos & Easter Bush & Bugac \\
\hline Coordinates & $\begin{array}{l}61^{\circ} 50^{\prime} 51^{\prime \prime} \mathrm{N} \\
24^{\circ} 17^{\prime} 41^{\prime \prime} \mathrm{E}\end{array}$ & $\begin{array}{l}58^{\circ} 52^{\prime} 30^{\prime \prime} \mathrm{N} \\
26^{\circ} 15^{\prime} 33^{\prime \prime} \mathrm{E}\end{array}$ & $\begin{array}{l}55^{\circ} 29^{\prime} 13^{\prime \prime} \mathrm{N} \\
11^{\circ} 38^{\prime} 45^{\prime \prime} \mathrm{E}\end{array}$ & $\begin{array}{l}52^{\circ} 15^{\prime} 08^{\prime \prime} \mathrm{N} \\
5^{\circ} 15^{\prime} 08^{\prime \prime} \mathrm{E}\end{array}$ & $\begin{array}{l}55^{\circ} 51^{\prime} 52^{\prime \prime} \mathrm{N} \\
3^{\circ} 12^{\prime} 25^{\prime \prime} \mathrm{W}\end{array}$ & $\begin{array}{l}46^{\circ} 40^{\prime} 59^{\prime \prime} \mathrm{N} \\
19^{\circ} 36^{\prime} 0^{\prime \prime} \mathrm{E}\end{array}$ \\
\hline Altitude (m) & 181 & 80 & 40 & 52 & 193 & 111 \\
\hline Climate & Boreal & Hemiboreal & Maritime temperate & Oceanic temperate & Oceanic temperate & $\begin{array}{l}\text { Temperate semi-arid } \\
\text { (Pannonian) }\end{array}$ \\
\hline Ecosystem type & Forest & Forest & Forest & Forest & Intensive grassland & Grassland \\
\hline Species & Pinus sylvestris & Pinus sylvestris & Fagus sylvatica & Pseudotsuga menziesii & Lolium perenne & Festuca pseudovina \\
\hline Year of plantation & 1962 & 1975 & $\sim 1920$ & 1962 & 1960 & \\
\hline $\begin{array}{l}\text { Average stand height in } \mathrm{m} \\
\text { (year of measurement) }\end{array}$ & $16.3(2006)$ & $11(2009)$ & $25(2006)$ & $32(2006)$ & - & - \\
\hline Total specific leaf area $\left(\mathrm{m}^{2} \mathrm{~kg}^{-1}\right)$ & 8.13 & 6.05 & 28.65 & 9.39 & 17.78 & 24.47 \\
\hline Initial litter $\mathrm{C}$ content $(\%)$ & 46.68 & 46.69 & 45.87 & 48.31 & 44.18 & 44.01 \\
\hline Initial litter $\mathrm{N}$ content $(\%)$ & 0.39 & 1.24 & 0.98 & 1.52 & 0.67 & 1.62 \\
\hline Start date (year 2009) & 5 Oct & 9 Oct & $17 \mathrm{Nov}$ & 19 Nov & $2 \mathrm{Nov}$ & 9 Nov \\
\hline Decomposition period $(\mathrm{d})$ & 368 & 357 & 359 & 367 & 367 & 376 \\
\hline Total cumulative air temperature $\left({ }^{\circ} \mathrm{C} \text { day }\right)^{*}$ & 2404 & 2759 & 2969 & 3574 & 3153 & 4193 \\
\hline Annual mean air temperature $\left({ }^{\circ} \mathrm{C}\right)$ & 3.4 & 5.1 & 7.6 & 9.4 & 8.3 & 10.9 \\
\hline Annual mean soil temperature $\left({ }^{\circ} \mathrm{C}\right)$ & 5.6 & 7.7 & 7.4 & 8.3 & 8.2 & 11.4 \\
\hline Precipitation $(\mathrm{mm})$ & 511 & 725 & 878 & 871 & 744 & 838 \\
\hline FAO soil type & Haplic podzol & Histic gleysol & Oxyaquic hapludalf & Orthic podsol & Eutric cambisol & Chernozem \\
\hline Soil water content (\%) & 23.95 & 28.73 & 21.13 & 38.57 & 27.57 & 9.96 \\
\hline Soil texture & Sandy loam & Sandy loam & Loamy sand & Silty sand & Sandy loam & Loess \\
\hline Soil depth (cm) & 61 & 200 & 85 & 100 & 100 & 50 \\
\hline Soil pH $(5 \mathrm{~cm})$ & 3.3 & 2.2 & 4.6 & 3.7 & 5.1 & 7.3 \\
\hline
\end{tabular}

* Cumulative degree-days accounting for days with mean temperature higher than $0{ }^{\circ} \mathrm{C}$ over the decomposition period.

\subsection{Analysis of carbon and nitrogen contents and leaf traits}

The content of each litter bag was ground to a fine powder and the total $\mathrm{C}$ and $\mathrm{N}$ content per dry mass was determined by a Vario MAX CNS elemental analyzer (Elementar Analysensysteme GmbH, Hanau, Germany) to the nearest $0.01 \%$. The litter $\mathrm{N}$ content at different times since the start of decomposition, and the litter $\mathrm{N}$ content at the end of the first year of decomposition $\left(\mathrm{N}_{\mathrm{f}}\right)$ were normalized with respect to the initial litter content $\left(\mathrm{N}_{0}\right)$ to estimate the relative $\mathrm{N}$ loss through the decomposition treatment.

Specific leaf area was measured in a subsample of the initial (not subjected to decomposition) dried litter mixture. Leaf samples were weighed ( 0.5 to $1 \mathrm{~g}$ ) and carefully spread over an A4 flatbed scanner glass avoiding overlap between the leaves, and the leaves were scanned at $300 \mathrm{dpi}$. The RGB colour image of the leaves was processed to estimate the projected litter specific leaf area $\left(\mathrm{m}^{2} \mathrm{~kg}^{-1}\right)$ as described by Portillo-Estrada et al. (2015). The total specific leaf area was estimated from the projected specific leaf area by considering different leaf section shapes for different leaf types: the section of Festuca pseudovina was approximated to a circle; the section of Pinus sylvestris leaves was considered to be hemicircular; Fagus sylvatica and Lolium perenne leaves were considered flat, thus the projected area was multiplied by two; and for Pseudotsuga menziesii, the projected specific leaf area was multiplied by a factor of 2.3 obtained from measurements of needle circumference to width ratio from the leaf cross-sections under a light microscope. The total specific leaf area represented the maximum leaf surface exposed to potential microbial attack and other physical agents during decomposition.

\subsection{Litter decomposition rate}

The annual decomposition rate constant, $k$ (year ${ }^{-1}$ ) (Olson, 1963) was calculated by fitting the fraction of litter mass remaining vs. time of sampling relationships according to the equation:

$\ln \left(m_{\mathrm{t}} / m_{0}\right)=-k t$,

where $m_{\mathrm{t}}$ is the remaining mass of litter after time $t$ (year), and $m_{0}$ is the original mass of litter. Six log-transformed data points (five sampling times plus the initial litter mass) corresponding to the average litter mass of the three replicate bags harvested at each decomposition time step were used in each case.

A pairwise comparison (Holm-Sidak at a significance level of $P<0.05$ ) test was used to find differences in $k$ between litter types across the decomposition sites.

Litter turnover rate (year) was estimated as the inverse of $k$ (Feng, 2009).

\subsection{Meteorological data}

Data on air temperature at 0.5 to $4 \mathrm{~m}$ height and soil temperature at $2 \mathrm{~cm}$ depth, precipitation, air relative humidity and soil water content at $6 \mathrm{~cm}$ depth were retrieved from the $\mathrm{Ni}$ troEurope database (Owen et al., 2011). The retrieved $30 \mathrm{~min}$ average air and soil temperature data were averaged daily and a mean annual air $\left(T_{\mathrm{a}}\right)$ and soil $\left(T_{\mathrm{S}}\right)$ temperatures were calculated for each site. As the sites spanned over a wide climatic 
gradient (Table 1), two additional variables for cumulative temperature were created, one for soil $\left(T_{\mathrm{c}, \mathrm{s}}>0\right)$ and another for air temperature $\left(T_{\mathrm{c}, \mathrm{a}}>0\right)$. The characteristics were computed by summing up the Celsius degrees of days of which daily average temperature was above $0{ }^{\circ} \mathrm{C}$ from the start date of the decomposition until the date of the litter collection. These excluded the time periods when water was frozen, and better characterized the control of temperature on the decomposition process. This suggestion was tested in the following analysis.

\subsection{Modelling analysis}

In order to statistically predict the percentage of litter mass remaining from the initial litter mass $\left(M_{\mathrm{r}}\right)$ and the $\mathrm{C}$ and $\mathrm{N}$ contents in litter relative to initial values $\left(\mathrm{C}_{\mathrm{r}}\right.$ and $\left.\mathrm{N}_{\mathrm{r}}\right)$ at a certain decomposition time, we generated linear mixedeffect models including all meteorological parameters and their two-way interactions that individually presented high explanatory power (Pearson correlation coefficient) with the key dependent variables: cumulative air and soil temperature ( $T_{\mathrm{c}, \mathrm{s}>0}$ and $T_{\mathrm{c}, \mathrm{a}>0}$ ), cumulative precipitation, air relative humidity, and soil water content. Land use was included as a two-level categorical factor (forests and grasslands) in all models as well, and $M_{\mathrm{r}}$ was used as an additional independent variable in the models of $\mathrm{C}$ and $\mathrm{N}$. Litter origin was used as a random factor in all models.

Minimum value of the Akaike information criterion (AICvalue) was used as the criterion for choosing the best model. AIC is a measure of the relative quality of a statistical model for a given set of data. Models with an AIC value differing by $\leq 5$ were considered equivalent. We ended up with relatively simple models for the four studied characteristics $\left(M_{\mathrm{r}}, \mathrm{C}_{\mathrm{r}}, \mathrm{N}_{\mathrm{r}}\right.$ and $k$ rate). Model selection was done in $\mathrm{R}$ (R Core Team, 2013), with the package nlme: linear and nonlinear mixedeffects models (Pinheiro et al., 2013).

\section{Results}

\subsection{Litter mass loss during decomposition}

The decomposition during the first 100 days was faster than that in the remaining period in all sites and for all types of litter (Fig. 1). Analysis of the early-stage decomposition at Hyytiälä further indicated that the mass loss rate (6 to 12\%) was most pronounced during the first couple of days of decomposition (Fig. 1g). This rapid loss was followed by a slow down in the decomposition and a small increase in the litter mass in the subsequent days so that in 1 month $87-92 \%$ of initial mass was remaining (Fig. 1g). After 3 months of decomposition, we identified a general decrease in the mass loss rate in all the forest and grassland sites (Fig. 1a-f). In all the sites and litter species, there was a general drop in litter remaining mass during the first months followed by a constant mass over the period of 100-200 days corresponding to the winter period, and more pronounced where a snow cover was present (Fig. 1c, d).

The tree litter remaining mass after 1 year of decomposition differed between the litters of different origin when decomposing in the same site. Nevertheless, a trend of higher remaining mass in the northern sites Hyytiälä (mean \pm SE value was $71.0 \pm 2.7 \%)$ and Männikjärve $(69.1 \pm 1.8 \%)$ was observed when compared to the more Southern sites Sorø $(61.5 \pm 2.4 \%)$ and Speulderbos $(56.9 \pm 4.6 \%)$ (Fig. 1a-d). In more detail, the decomposition of conifer litter followed a similar trend in all forest sites, characterized by a greater mass loss than that for the broadleaved beech litter. This difference was more pronounced at the sites with a higher mean annual air temperature (Table 1), with Speulderbos being the site where the remaining mass differed most between conifer and broadleaved litter types. Regarding the conifer litter, Douglas fir (Pseudotsuga menziesii) litter decomposed faster in the first months than Pinus sylvestris litter in Sorø, Männikjärve and Hyytiälä (Fig. 1b, c, d). The remaining mass of Pinus sylvestris over the decomposition period did not differ ( $P=0.392$; paired Student's $t$ test) between the litter originated at Hyytiälä and Männikjärve. Also there was no difference ( $P=0.669$; paired Student's $t$ test) in the remaining mass at the end of the decomposition.

The temporal dynamics of the remaining mass of grass litter was very similar for both types of litter (Fig. 1e, f). After 1 year of decomposition, the remaining mass of litter was substantially smaller at Easter Bush (mean value $19.8 \%$ ) than at Bugac (46.6\%).

The average standard error for the three replicate litter bags of the litter mass remaining after 1 year was $0.7 \%$ across all sites. Within the given site, the litter mass remaining after 1 year since the start of the decomposition did not show differences among leaf litters with different origin (One way repeated measures ANOVA test, $P>0.05$; Fig. 1 ). Thus, the decomposition showed a marked dependency on the decomposition site characteristics, rather than on litter type. As an exception, mass loss of Fagus sylvatica litter from Sorø decomposed in Speulderbos was slower than that of conifer litters (Holm-Sidak pairwise multiple comparison test, $P<0.05$; Fig. 1a).

The values of the decomposition rate constant, $k$, were calculated as the slope of a linear fit $(N=6)$ using logtransformed data of remaining litter mass (Eq. 1). The Pearson correlation coefficient $(r)$ across all species and sites was very high (average \pm SE of $0.940 \pm 0.010 ; P<0.05$ in all cases). Decomposition $k$ rate was negatively correlated with the total specific leaf area in tree species $\left(r^{2}=0.38\right.$; $P=0.011)$, but did not correlate to the initial $\mathrm{N}$ content $\left(r^{2}=0.021 ; P=0.59\right)$. 


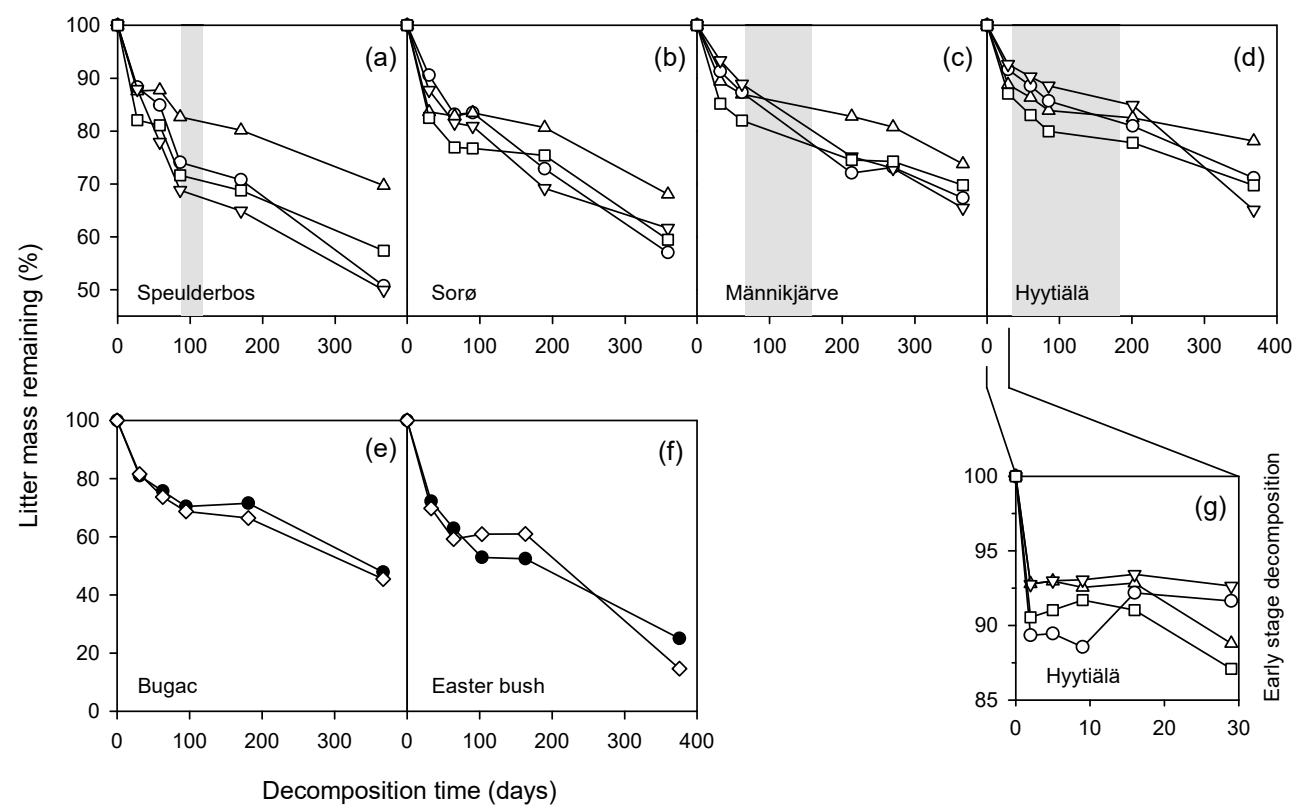

Figure 1. Average remaining leaf litter mass during a reciprocal litter transplantation experiment of four tree litter types during decomposition in four forest sites $(\mathbf{a}, \mathbf{b}, \mathbf{c}, \mathbf{d})$ and grass litter types during decomposition in two grassland sites (e, f). Different symbols stand for different sites of litter origin (and typically a different species, except the northernmost sites Hyytiälä and Männikjärve): Pinus sylvestris $(O)$ from Hyytiälä (Finland), P. sylvestris $(\nabla)$ from Männikjärve (Estonia), Fagus sylvatica $(\Delta)$ from Sorø (Denmark), Pseudotsuga menziesii $(\square)$ from Speulderbos (Netherlands) (e) Festuca pseudovina $(\diamond)$ from Bugac (Hungary) and (f) Lolium perenne (•) from Easter Bush (UK). Data points are the average of three replicate litter decomposition bags (maximum standard error between replicates during the decomposition of $4.7 \%$, not plotted). The shadowed areas correspond to the winter period where the litter bags were covered by a snow layer of at least $3 \mathrm{~cm}$. (g) corresponds to early-stage decomposition for tree litter types in Hyytiälä. Table 1 provides details of the sample sites and litter characteristics.

\subsection{Relationships between litter decomposition rates and site climatic characteristics}

$T_{\mathrm{a}}$ and $P$ for different decomposition sites were positively correlated $\left(r^{2}=0.57\right)$, although marginally significant $(P=0.08 ; N=6)$. Cumulative air temperature $\left(T_{\mathrm{c}, \mathrm{a}}>0\right)$ and cumulative precipitation $\left(P_{\mathrm{c}}\right)$ measured at each sampling time during the year were positively correlated across the sites $\left(r^{2}=0.91 ; P<0.0001\right)$. Cumulative soil water content $\left(W_{\mathrm{c}}\right)$ was positively correlated with $P_{\mathrm{c}}\left(r^{2}=0.81\right.$; $P<0.0001)$ and $T_{\mathrm{c}, \mathrm{a}}>0\left(r^{2}=0.70 ; P<0.0001\right)$.

Collectively, the remaining litter mass at different stages of decomposition was negatively correlated with $T_{\mathrm{a}}>0$ and $P$ in forest (Fig. 2a, b) and grassland (Fig. 2c, d) sites.

The decomposition rate constants, $k$, of all forest decomposition experiments together correlated positively with the mean annual temperature $\left(T_{\mathrm{a}}\right)$ of the decomposition site $\left(r^{2}=0.45 ; P=0.0043\right.$; Fig. 3a). The correlation was high for each individual litter type: $r^{2}=0.99(P=0.0065)$ for Pinus sylvestris (Hyytiälä), $r^{2}=0.80(P=0.10)$ for Pinus sylvestris (Männikjärve), $r^{2}=0.91(P=0.045)$ for Fagus sylvatica (Sorø), and $r^{2}=0.94(P=0.029)$ for Pseudotsuga menziesii. The value of $k$ was also positively correlated with the site mean annual precipitation $(P)$ (Fig. 3b). Analogously, the higher $T_{\mathrm{a}}$ and $P$, the more litter mass was lost after 1 year of decomposition (Fig. 3c, d). As a consequence of the correlations of mass loss and $k$ with site climatic variables, the estimated litter turnover time was negatively correlated with $T_{\mathrm{a}}$ (Fig. 3e) and $P$ (Fig. 3f).

The values of $k$ at each site were lower for the broadleaved Fagus sylvatica (Sorø) litter compared to the conifer Pinus sylvestris (Hyytiälä) $(P=0.001)$ and Pinus sylvestris (Männikjärve) $(P=0.002)$ litter types, and marginally significantly lower from the $k$ values for Pseudotsuga menziesii $(P=0.060)$. Similarly, the pairwise tests showed that the litter mass loss after 1 year of decomposition (Fig. 3c, d) and estimated turnover time (Fig. 3e, f) calculated for each site depended on the litter type, showing statistical differences between the broadleaved Fagus sylvatica (Sorø) litter and the other three conifer litter types, with no differences between conifer litters.

\subsection{Litter carbon and nitrogen contents through decomposition}

Analogously to litter mass, $\mathrm{C}$ and $\mathrm{N}$ contents were expressed relative to the initial level at the beginning of the decomposition in order to compare the dynamics along different litter types (Fig. 4). Pooling all the decomposition data together, forest litter $\mathrm{C}$ content non-linearly increased during the de- 


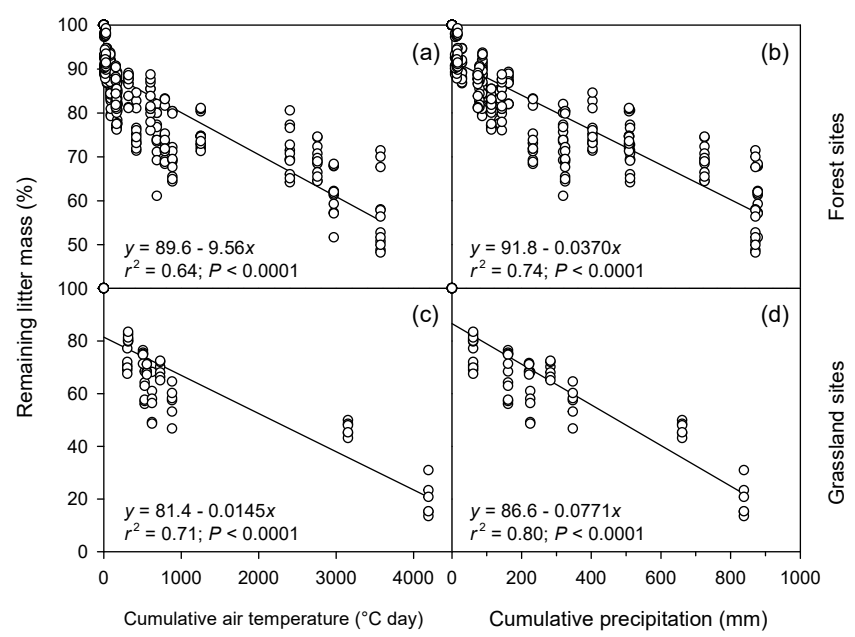

Figure 2. Average remaining biomass during first year decomposition of leaf litter of four tree species in four forest sites $(\mathbf{a}, \mathbf{b})$ and grass litter from two species in two grasslands (c, d) across Europe (see Table 1 for details). The cumulative air temperature is the sum of daily average temperatures above $0^{\circ} \mathrm{C}$ from the beginning of the decomposition period until the date of litter collection for every litter bag. The cumulative precipitation is the sum of daily precipitation (in $\mathrm{mm}$ ) from the beginning the decomposition period until the date of litter collection. The solid lines represent the Pearson's linear regression best fit ( $n=336$ for forest sites and $n=72$ for grassland sites).

composition process (Fig. 4a), in contrast with grassland litter, that remained constant through the decomposition period (Fig. 4b). Litter $\mathrm{N}$ content increased during the first year of decomposition for both forest and grassland litters (Fig. 4c, d), although during the first 10 days of decomposition it remained constant for the four forest litter types at Hyytiälä (Fig. 4c inset). Therefore, the $\mathrm{C}: \mathrm{N}$ ratio steadily decreased during the first year for both types of litter (Fig. 4e, f).

The litter $\mathrm{N}$ content after different decomposition periods relative to the initial value was positively correlated with the cumulative litter mass loss across all decomposition experiments (Fig. 5). However, there was a slight decrease of litter $\mathrm{N}$ content during the first period of decomposition (at around $10 \%$ of cumulative mass loss) (Fig. 5).

The final to initial $\mathrm{N}$ content ratio $\left(\mathrm{N}_{\mathrm{f}}: \mathrm{N}_{0}\right)$ in the forest litter showed a positive trend if plotted against site's $T_{\mathrm{a}}$ and $P$ (Fig. 3g, h) such that at warmer and more humid decomposition sites, litter $\mathrm{N}$ content increased more than at colder and drier sites.

\subsection{Results of the statistical modelling analysis}

The best model for $M_{\mathrm{r}}$ contained three independent cumulative meteorological variables, air temperature and precipitation, soil water content and the site type factor (grassland or forest), while the models for both $\mathrm{C}$ and $\mathrm{N}$ were strongest with only remaining litter mass, air temperature and land-use.

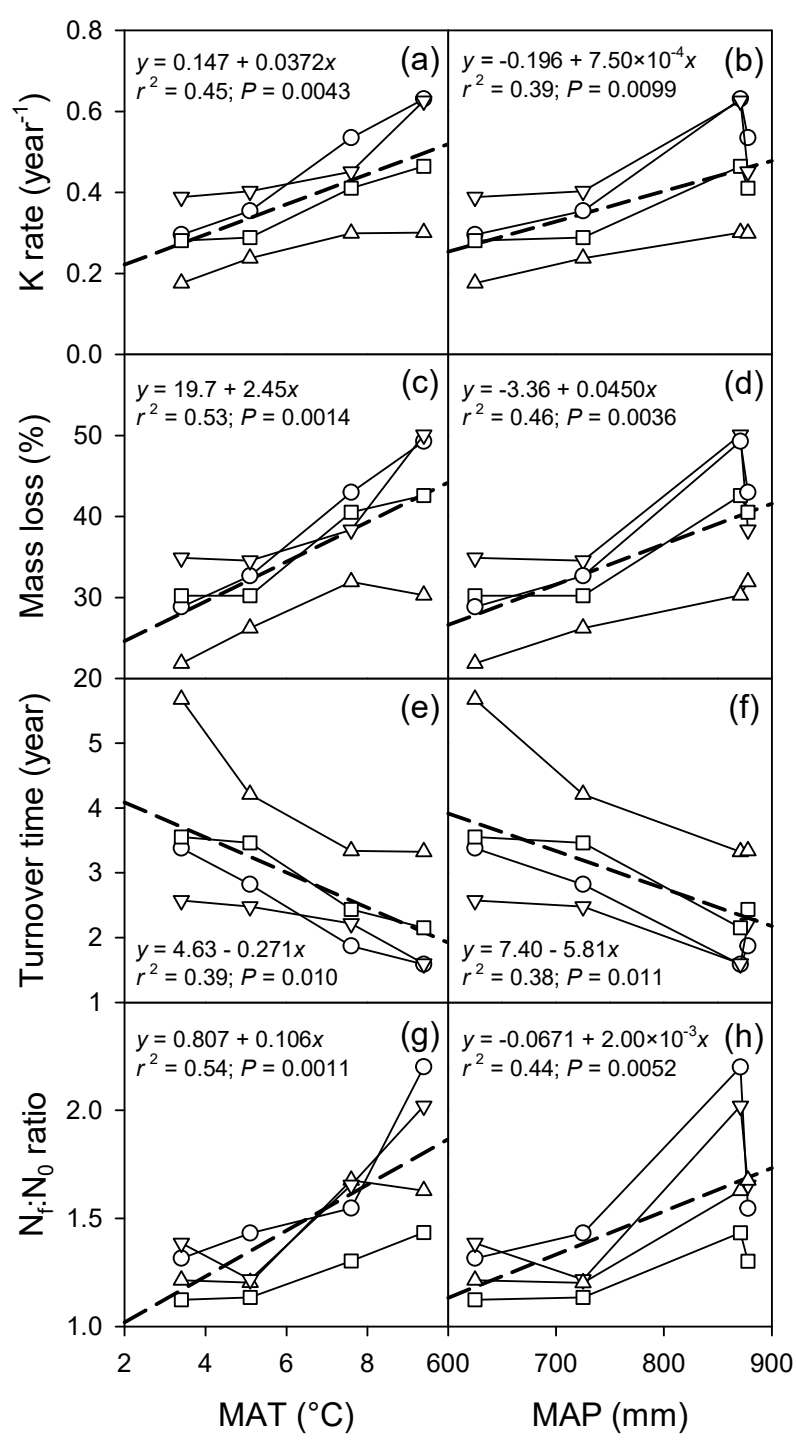

Figure 3. Litter decomposition traits of four different tree litter species with different origin decomposed in four European sites with different mean annual temperature $\left(T_{\mathrm{a}}\right)$ and mean annual precipitation $(P)$. Symbols as in Fig. 1. Data corresponding to the same origin of litter are connected with a solid line to visually evaluate the evolution of the trait across the $T_{\mathrm{a}}$ and $P$ range. The dashed line represents the Pearson's linear regression best fit of all the data. Traits are first-year decomposition $k$ rate $(\mathbf{a}, \mathbf{b})$, percentage of mass loss after 1 year of decomposition relative to initial mass $(\mathbf{c}, \mathbf{d})$, estimated litter turnover time $(\mathbf{e}, \mathbf{f})$, and ratio between final litter $\mathrm{N}$ content $\left(\mathrm{N}_{\mathrm{f}}\right)$ after 1 year of decomposition and the initial nitrogen content $\left(\mathrm{N}_{0}\right)$.

The percentage of remaining litter mass relative to the initial value $\left(M_{\mathrm{r}}\right)$ at forest sites was calculated as

$$
\begin{aligned}
M_{\mathrm{r}} & =94.51-0.04873 \times P_{\mathrm{c}}+0.00959 \times T_{\mathrm{c}, \mathrm{a}}>0 \\
& -0.00206 \times W_{\mathrm{c}},
\end{aligned}
$$




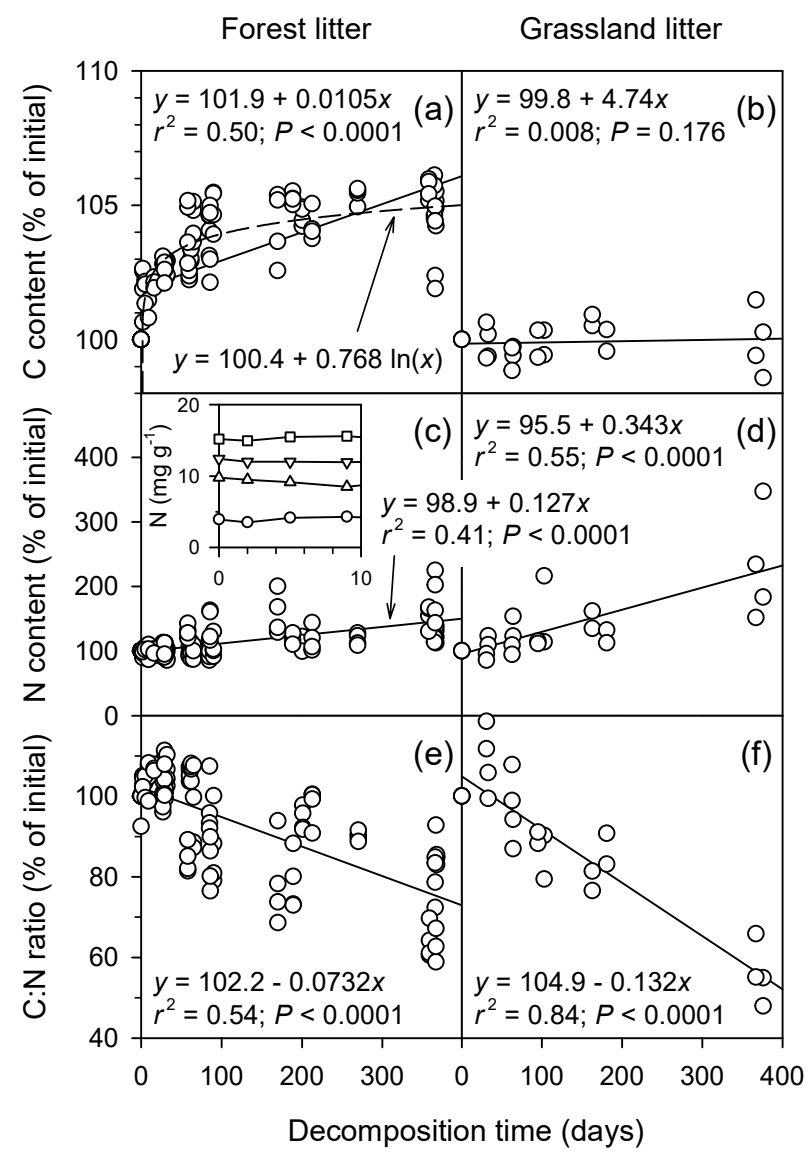

Figure 4. Total $\mathrm{C}, \mathrm{N}$ and $\mathrm{C}: \mathrm{N}$ ratio relative to the initial level at the beginning of the decomposition period. The data correspond to reciprocal litter transplantation experiments with leaf litter from forests sites: Pinus sylvestris (Hyytiälä, Finland), Pinus sylvestris (Männikjärve, Estonia), Fagus sylvatica (Sorø, Denmark), and Pseudotsuga menziesii (Speulderbos, Netherlands); and grassland sites: Lolium perenne (Easter Bush, UK) and Festuca pseudovina (Bugac, Hungary). Data points $(N=112$ for tree litter and $N=24$ for grass litter) are the average value of three litter bags. In (a), the dashed line represents the best logarithmic fit to the data. The inset in (c) represents the $\mathrm{N}$ content in leaf litter during the first 10 days of decomposition. Symbols stand for P. sylvestris from Hyytiälä $(O)$ and Männikjärve $(\nabla), F$. sylvatica $(\Delta)$, and P. menziesii $(\square)$.

and for grassland sites as

$$
\begin{aligned}
M_{\mathrm{r}} & =84.63-0.04873 \times P_{\mathrm{c}}-0.00059 \times T_{\mathrm{c},} \mathrm{a}>0 \\
& -0.00206 \times W_{\mathrm{c}},
\end{aligned}
$$

where $P_{\mathrm{c}}$ is the cumulative precipitation $(\mathrm{mm}), T_{\mathrm{c}, \mathrm{a}>0}$ the cumulative air temperature $\left({ }^{\circ} \mathrm{C}\right)$ on days where daily average temperature was above $0^{\circ} \mathrm{C}$, and $W_{\mathrm{c}}$ is cumulative soil water content in percentage.

The percentage of carbon content in litter relative to the initial value $\left(\mathrm{C}_{\mathrm{r}}\right)$ at forest sites was calculated as

$\mathrm{C}_{\mathrm{r}}=117.86-0.17172 \times M_{\mathrm{r}}-0.00041 \times T_{\mathrm{c}, \mathrm{a}}>0$,

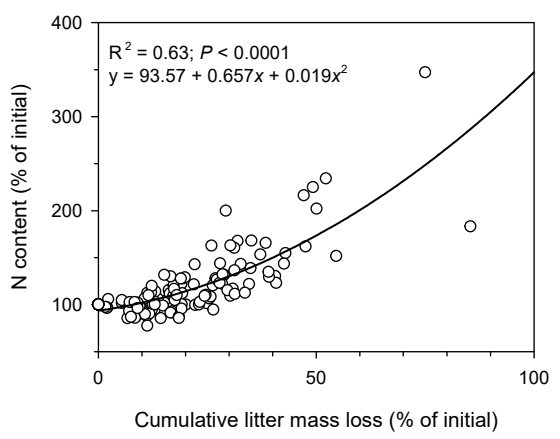

Figure 5. Second-order polynomial relationship between the cumulative litter mass loss (in percentage of initial) of leaf litter of Pinus sylvestris (Hyytiälä, Finland), Pinus sylvestris (Männikjärve, Estonia), Fagus sylvatica (Sorø, Denmark), and Pseudotsuga menziesii (Speulderbos, Netherlands), Lolium perenne (Easter Bush, UK) and Festuca pseudovina (Bugac, Hungary) and the litter N content relative to initial during a reciprocal litter transplantation decomposition experiment. Data points $(n=136)$ are the average value of three replicate litter bags.

and for grassland sites as

$\mathrm{C}_{\mathrm{r}}=99.23+0.01081 \times M_{\mathrm{r}}-0.00041 \times T_{\mathrm{c}, \mathrm{a}}>0$.

The percentage of nitrogen content in litter relative to the initial value $\left(\mathrm{N}_{\mathrm{r}}\right)$ at forest sites and grasslands was calculated as

$$
\begin{aligned}
\mathrm{N}_{\mathrm{r}} & =187.51-0.9282 \times M_{\mathrm{r}} \\
& -0.03156 \times T_{\mathrm{c}, \mathrm{a}}>0-0.00037 \times M_{\mathrm{r}} \times T_{\mathrm{c}, \mathrm{a}}>0 .
\end{aligned}
$$

In addition, the decomposition $k$ rate was calculated by a linear model $\left(r^{2}=0.96 ; P<0.0001\right)$ as a function of site's mean annual air temperature accounting days with daily average above $0{ }^{\circ} \mathrm{C}\left(T_{\mathrm{a}}>0\right)$, mean annual precipitation $(P)$, mean soil water content in percentage $(W)$, and litter total specific leaf area $\left(S_{\mathrm{LA}}\right)$ as

$$
\begin{aligned}
k & =4.711-0.8601 \times T_{\mathrm{a}>0}-0.0040 \times P+0.02162 \times W \\
& -0.02140 \times S_{\mathrm{LA}}+0.000827 \times T_{\mathrm{a}}>0 \times P \\
& -0.00373 \times T_{\mathrm{a}>0} \times S_{\mathrm{LA}},
\end{aligned}
$$

and for grassland sites as,

$$
\begin{aligned}
k & =5.425-0.8601 \times T_{\mathrm{a}}>0-0.0040 \times P+0.02162 \times W \\
& -0.05761 \times S_{\mathrm{LA}}+0.000827 \times T_{\mathrm{a}}>0 \times P \\
& -0.00373 \times T_{\mathrm{a}}>0 \times S_{\mathrm{LA}} .
\end{aligned}
$$

The $P$ values as well as individual standard errors of the modelled parameters for each equation can be seen in Table 2. In Fig. 6 we plot the modelled data $\left(M_{\mathrm{r}}, \mathrm{C}_{\mathrm{r}}, \mathrm{N}_{\mathrm{r}}\right.$, and $\left.k\right)$ against the observed. 
Table 2. Individual estimates (with $t$ value and $P$ values) of the parameters modelled in Eqs. (2) to (8). The predictors which contain "site " apply for models corresponding to grassland sites. In these cases, the resulting value is the result of the addition of the original predictor lacking of "site $\mathrm{g}$ " and the predictor containing "site $\mathrm{g}$. $P_{\mathrm{c}}$ is cumulative precipitation, $T_{\mathrm{c}, \mathrm{a}}>0$ is the cumulative of daily average air temperatures higher than zero degrees Celsius, $W_{\mathrm{c}}$ is the cumulative daily average soil water content, $P$ is mean annual precipitation, $T_{\mathrm{a}>0}$ is mean annual temperature accounting for days with positive temperatures, $W$ is mean annual soil water content, and $S_{\mathrm{LA}}$ is the total specific leaf area.

\begin{tabular}{|c|c|c|c|c|}
\hline \multirow[t]{2}{*}{ Predictor } & \multicolumn{4}{|c|}{ Independent variable } \\
\hline & $\begin{array}{r}\text { Remaining litter mass } \\
\left(M_{\mathrm{r}}\right)(\% \text { relative to initial })\end{array}$ & $\begin{array}{l}\text { Remaining litter } \mathrm{C} \text { content } \\
\left(\mathrm{C}_{\mathrm{r}}\right)(\% \text { relative to initial })\end{array}$ & $\begin{array}{l}\text { Remaining litter } \mathrm{N} \text { content } \\
\left(\mathrm{N}_{\mathrm{r}}\right)(\% \text { relative to initial })\end{array}$ & $\begin{array}{r}k \text { decomposition rate } \\
\left(\text { year }^{-1} \text { ) }\right.\end{array}$ \\
\hline Intercept & $94.50946(37.5 ;<0.0001)$ & $117.86852(96.5 ;<0.0001)$ & $187.51119(15.9 ;<0.0001)$ & $4.7107576(3.30 ; 0.007)$ \\
\hline Intercept + site $_{g}$ & $-9.87787(-2.25 ; 0.087)$ & $-18.63872(-16.3 ; 0.0001)$ & & $0.7145248(5.18 ;<0.0003)$ \\
\hline$P_{\mathrm{c}}$ & $-0.04873(-8.07 ;<0.0001)$ & & & \\
\hline$T_{\mathrm{c}, \mathrm{a}}>0$ & $0.00959(7.78 ;<0.0001)$ & $-0.00041(-2.72 ; 0.0068)$ & $0.03156(7.66 ;<0.0001)$ & \\
\hline$T_{\mathrm{c}, \mathrm{a}}>0+$ site $_{\mathrm{g}}$ & $-0.01018(-13.3 ;<0.0001)$ & & & \\
\hline$W_{\mathrm{c}}$ & $-0.00206(-7.97 ;<0.0001)$ & & & \\
\hline$M_{\mathrm{r}}$ & & $-0.17172(-12.6 ;<0.0001)$ & $-0.92815(-7.16 ;<0.0001)$ & \\
\hline$M_{\mathrm{r}}+$ site $_{\mathrm{g}}$ & & $0.18253(12.5 ;<0.0001)$ & & \\
\hline$M_{\mathrm{r}}: T_{\mathrm{c}, \mathrm{a}}>0$ & & & $-0.00037(-6.07 ;<0.0001)$ & \\
\hline$P$ & & & & $-0.0040002(-2.55 ; 0.027)$ \\
\hline$T_{\mathrm{a}}>0$ & & & & $-0.8600745(-3.89 ; 0.0025)$ \\
\hline$W$ & & & & $0.0216207(8.94 ;<0.0001)$ \\
\hline$S_{\mathrm{LA}}$ & & & & $0.0213956(1.71 ; 0.11)$ \\
\hline$S_{\mathrm{LA}}+$ site $_{\mathrm{g}}$ & & & & $0.0362101(5.67 ; 0.0001)$ \\
\hline$P: T_{\mathrm{a}}>0$ & & & & $0.0008268(3.42 ; 0.0057)$ \\
\hline$T_{\mathrm{a}>0}: S_{\mathrm{LA}}$ & & & & $-0.0037277(-2.44 ; 0.033)$ \\
\hline
\end{tabular}

\section{Discussion}

\subsection{Litter mass loss during decomposition}

Decomposition experiments usually do not focus on the very first days of decomposition (e.g. Vestgarden, 2001) but measure the remaining litter mass in monthly intervals after the beginning of the decomposition. However, there are experiments showing that the remaining mass data over time follows a curvilinear relationship (Pérez-Suárez et al., 2012), thus assuming that the highest mass loss rate occurs during the first days. Our study confirms with experimental data that the mass loss measured at Hyytiälä after 1 month of decomposition is mainly due to the high mass loss occurring in the very first days, being the absolute maximum rate of the decomposition during the whole period. This few-days period, known as the leaching phase, is driven by the loss of waterextractable compounds that physically leak from the sample (Berg and Laskowski, 2005; Cotrufo et al., 2015). As a conclusion, we assumed that litter mass loss followed a simple exponential decay function from the second day of decomposition, thus a double exponential model to calculate $k$ decomposition rate would not apply to our data.

Further in the first month of decomposition, we observed variations in the remaining litter mass including mass increases relative to the previous sampling during the first month of decomposition (Fig. 1g). This could be related to the invasion of microorganisms: mainly fungal mycelia and microbes (Dighton, 2007). Variations in the remaining lit- ter mass have also been shown in later periods than the first month (Liu et al., 2015; Gallardo and Merino, 1993), and has seldom been studied during the first days. Hence, this is yet another motivation to measure the decomposition process during the first days of the experiment focusing on the dynamics of microbial activity and colonization of the litter substrate.

After 3 months of decomposition, the litter mass loss rate decreased generating a plateau shape at around 100 days of decomposition as observed in Fig. 1. This was also found by other authors (Liu et al., 2015; Zhang et al., 2014). The generation of a plateau was not noticeable in the litter decomposed in Männikjärve (Fig. 1c) because the third sampling was not done during the snow cover period but after it. We speculate that the dynamic of the litter remaining mass could have been similar to the one observed at Hyytiälä (Fig. 1d), revealing also a noticeable decrease in the decomposition rate during the winter after 3 months of decomposition. We theorize that the slower decomposition rate phase was generated by the combination of the following factors: firstly, this period coincided with the winter period, where lower air and soil temperature and the presence of a snow cover or the lack of liquid water in some sites reduced the decomposition rate. To corroborate this hypothesis, we found that the remaining biomass and the input of heat to the system estimated by the cumulative air temperature were correlated (Fig. 2a, c). In addition, the decomposition rate increased after the winter period. Secondly, the decomposition usually begins by the more digestible fractions of the litter substrate 
such as soluble carbohydrates sucrose or glucose (Mansfield and Bärlocher, 2005), generating a faster decomposition rate during the first months. Consequently, after the initial leaching phase, when the substrate is less decomposable, the leaf litter mass loss rate slows down, and collectively with the winter effect creating a plateau.

In most of the cases, the remaining litter mass did not depend on the litter type, being statistically similar during the decomposition for each site. The exception was Fagus sylvatica litter from Sorø when decomposed in Speulderbos. In this case, after the pairwise comparison, two clearly distinct groups were identified, coinciding with the different nature of the leaf litter: the remaining mass of conifer litter differed with the broad-leaved deciduous leaf litter. The decomposition of grass litter types showed a strong influence by the decomposition sites' climatic characteristics and not between litter types. This was noticeable in the high similarity of the remaining litter mass dynamic of the grass litter when decomposing in the same site, as well as by the similar values achieved of remaining litter mass after 1 year of decomposition.

\subsection{Litter carbon and nitrogen contents during decomposition}

Nitrogen is released from leaf litter during decomposition firstly due to leaching and secondly because it is consumed as a substrate by decomposing organisms. Berg and Laskowski (2005) showed that the content of $\mathrm{N}$ in the litter sample increases with time of decomposition. They argued that litter is colonized by decomposing organisms and since $\mathrm{N}$ is usually a limiting nutrient to soil biota, it may actively be brought into the decomposing leaf through ingrowing fungal mycelia. As a result, the $\mathrm{N}$ content in the whole sample (including the litter substrate and the decomposers) increased. Our study corroborates the positive trend of $\mathrm{N}$ content over decomposition time (Fig. 4c, d) and cumulative mass loss (Fig. 5). These results make the current year litter layer an important sink of $\mathrm{N}$ during the first year of decomposition, being richer in $\mathrm{N}$ as climate is warmer and wetter (Fig. 3g, h). This can also have effects in the $\mathrm{N}$ turnover in future climate scenarios in the frame of a global change, since $T_{\mathrm{a}}$ and $P$ is predicted to increase during the present century for the Atlantic to boreal European climates, where our forest study sites are found (Jacob et al., 2014).

The litter $\mathrm{C}$ content during the decomposition followed a different dynamic between tree and grass litter types: the decomposition had almost no effect $\left(r^{2}=0.008\right)$ on the $\mathrm{C}$ content in grass litter whilst it resulted in a rise in the $\mathrm{C}$ content in tree litter. We hypothesize that fungal hyphae and mycorrhizae growing on the litter substrate could have brought considerable amounts of $\mathrm{C}$ and $\mathrm{N}$ onto the litter samples, and the overall $\mathrm{C}$ content in grass litter be biased by that increase, consequently keeping the carbon loss and carbon gain in equilibrium. Subsequently, the difference between tree and grass litter was taken into account as a random effect in the equations (Eqs. 4 and 5), and satisfactorily generated highly significant models for both land use types. We found no distinction between the prediction of $\mathrm{N}_{\mathrm{r}}$ during decomposition (Eq. 6) for grass and forest litter, supposedly because this is the limiting factor in all the ecosystems and $\mathrm{N}$ content dynamics were similar across the litter decomposing in all sites.

\subsection{Leaf litter decomposition traits across different climates and litter types}

The relationships studied with empirical data allowed us to generate a few models including most of the recurrent traits when studying litter decomposition: litter mass loss, and $\mathrm{C}$ and $\mathrm{N}$ contents during the decomposition process. Remarkably, the models for forest litter performed satisfactorily (Fig. 6) for different species and origins, including conifer and deciduous litter, with a high range of initial $\mathrm{N}$ and $\mathrm{C}$ contents and total specific leaf area. After the highly significant relationships between the litter remaining mass with the climatic characteristics (cumulative air temperature and precipitation), and the relationships between the decomposition rate, mass loss and litter turnover with $T_{\mathrm{a}}$ and $P$, we inferred that the climatic characteristics could be sufficient predictors for estimating the speed of the decomposition process. Additionally, we found that the models benefited from including the land use (forest/grassland) as a fixed factor. We observed that in the grassland sites, the remaining litter mass was highly influenced by the decomposition site characteristics and not by the litter species. Similarly, in the forest sites, there was a certain trend of lower remaining mass at a certain decomposition time as the site presented a warmer and wetter climate, resulting in a higher turnover rate, as studied by Kirschbaum (2000) in the American continent.

With this experiment we found two key points in the relationships of litter decomposition traits with the climatic variables. Firstly, the correlations of the litter traits (remaining mass, and $\mathrm{C}$ and $\mathrm{N}$ contents) with climatic variables (air temperature, precipitation, and soil water content) were better when transforming the climatic variables to cumulative instead of using annual climatic averages for the given sites. This allowed us to study the decomposition process as a function of the temperature and availability of moisture at each decomposition step during the year. Secondly, using $T_{\mathrm{c}, \mathrm{a}}>0$ allowed to overcome the fact that certain periods of the year are not favourable for decomposition; that is when the air temperature is $\leq 0$, water is frozen and microbial activity is essentially stopped. As shown previously, we detected that the decomposition slowed down during winter time as well as during snow cover periods, and therefore, discarding the days with mean temperature below $0{ }^{\circ} \mathrm{C}$ increased the significance of our models. This variable has certain resemblance to the degree days used to describe and predict plant growth, which usually uses the lower temperature limit at around $10^{\circ} \mathrm{C}$. As addressed in the introduction, using $T_{\mathrm{c}, \mathrm{a}}>0$ and $T_{>0}$ is espe- 


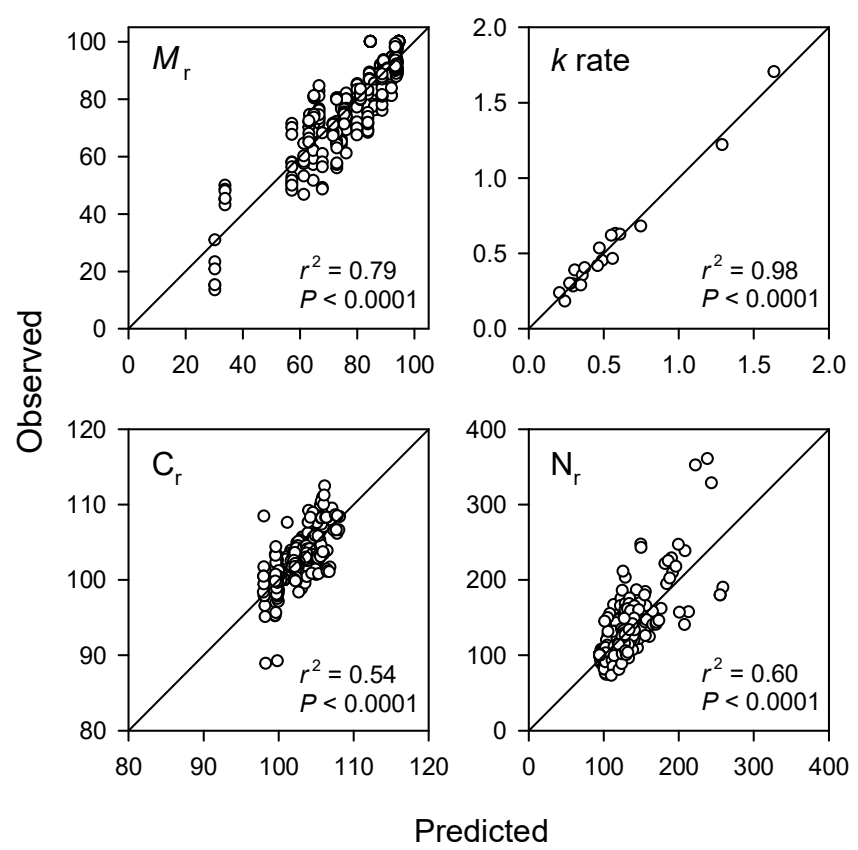

Figure 6. Modelled data using Eqs. (2-8) plotted against observed data: $\left(M_{\mathrm{r}}\right)$ the percentage of remaining litter mass relative to the initial value, $(k$ rate) litter decomposition rate constant, and the percentage of carbon $\left(\mathrm{C}_{\mathrm{r}}\right)$ and nitrogen $\left(\mathrm{N}_{\mathrm{r}}\right)$ content in litter relative to the initial value. For reference see $1: 1$ solid lines.

cially important for northern sites, which present long periods of freezing temperatures and litter decomposition is virtually stopped. We believe these variables should be taken in account for future modelling analysis and predictions.

Equations (2) and (3) performed a highly significant prediction for the litter mass remaining in the decomposition sites with only knowing $P_{\mathrm{c}}, T_{\mathrm{c}, \mathrm{a}}>0$, and $W_{\mathrm{c}}$, which is of paramount importance to extrapolating the litter turnover speed in these regions and in a climate change scenario. The importance of using cumulative variables in this particular case is that these can incorporate seasonal variations in the precipitation and temperature regimes, as is predicted to happen in Europe (Jacob et al., 2014).

We found high correlations between the cumulative precipitation $\left(P_{\mathrm{c}}\right)$ and air temperature $\left(T_{\mathrm{c}, \text { a }}>0\right)$ along the decomposition period, and individually with $\mathrm{C}_{\mathrm{r}}$ and $\mathrm{N}_{\mathrm{r}}$, and consequently the $\mathrm{C}_{\mathrm{r}}$ and $\mathrm{N}_{\mathrm{r}}$ models rejected one of both variables (Eqs. 4-6). This happens because using $T_{\mathrm{c}, \mathrm{a}}>0$ as a predictor for $\mathrm{C}_{\mathrm{r}}$ and $\mathrm{N}_{\mathrm{r}}$ was sufficient for explaining much of the observed variation, and adding $P_{\mathrm{c}}$ would not increase the explaining power of the models. Therefore, when including both climatic variables, the model AIC value increased, $P_{\mathrm{c}}$ was not significant and thus was discarded. Similarly, this happened with air and soil temperature variables $\left(T_{\mathrm{c}, \mathrm{a}}>0\right.$ and $T_{\mathrm{c}, \mathrm{s}}>0$ ) when the model rejected one of both, choosing $T_{\mathrm{c}, \mathrm{a}}>0$ as the most significant. In conclusion, because climatic variables were highly correlated with each other in our sites, in some cases the models rejected predictors which explained similarly the variation of the independent variables, and finally only a few predictors were needed for the models, which was one of the aims of this paper. Similarly, Liski et al. (2003) used few climatic parameters (air temperature, precipitation and evapotranspiration) to predict the litter firstyear mass loss. In the same way, our study was performed in a range of European climates which kept a certain relationship between $P$ and $T_{\mathrm{a}}$, therefore we cannot predict the performance of our models in more extreme climates where this relationship would not be kept (e.g. semi-arid climate in south-eastern Spain or subarctic climate in Lapland).

We found a strong effect of the climatic characteristics on the decomposition of different litter types, corroborated by similar trends in different litter types when decomposing in the same site. We found that the broad-leaved litter performed lower $k$ rates than the conifer litter, and this could be a consequence of significantly higher specific leaf area in the broad-leaved litter. Therefore, the prediction models of tree litter $k$ rates improved when including the initial total specific leaf area as a characteristic (Eqs. 7 and 8). On the contrary, the initial chemical composition ( $\mathrm{C}$ and $\mathrm{N}$ contents) was excluded from the equations.

Overall, despite having several climatic variables as inputs into the models, the AIC results were more favourable when the number of variables were less and the equations got simpler. In conclusion, having reached a simple model is in fact highly relevant when estimating these decomposition traits with few meteorological data available.

\section{Conclusions}

We found strong climatic influence driven by air temperature, precipitation and soil water content on the litter mass remaining during the first year of decomposition in different types of litter. Models with few climatic parameters were enough to predict the remaining litter mass, decomposition $k$ rate, $\mathrm{C}_{\mathrm{r}}$, and $\mathrm{N}_{\mathrm{r}}$ content with high certainty.

Leaf litter mass loss can be very important in the first couple of days of decomposition and it deserves special attention for future studies. Litter nitrogen content increased during the first year of decomposition as the litter remaining mass decreased and the climate was wetter and warmer.

The models generated better predictions when accounting for daily average air temperatures above $0^{\circ} \mathrm{C}$. Our models could be valid for extrapolation to other European climates where annual air temperature and precipitation are correlated, as it was in our case.

Author contributions. Miguel Portillo-Estrada, Mari Pihlatie and Ülo Niinemets designed the experiments. Miguel PortilloEstrada, Mari Pihlatie, Janne F. J. Korhonen, Janne Levula, Arnoud K. F. Frumau, Andreas Ibrom, László Horváth and Stephanie K. Jones carried out the field experiment. Miguel Portillo- 
Estrada, Jonas J. Lembrechts and Lourdes Morillas handled and analysed the data. Miguel Portillo-Estrada prepared the manuscript with contributions from all co-authors.

Acknowledgements. This work has been funded by the EU $7^{\text {th }}$ Framework Programme NitroEurope (8-2/T6018PKPK06), the Technical University of Denmark, the Academy of Finland Research Fellow projects $(263858,288494)$, The Academy of Finland Centre of Excellence (project 1118615), the Maj Tor Nessling Foundation, the Estonian Science Foundation through SA Archimedes (DoRa), the Estonian Ministry of Science and Education (institutional grant IUT-8-3), the European Commission through the European Regional Fund (the Center of Excellence in Environmental Adaptation), and the Flemish fund for scientific research (FWO).

We thank Endla Nature Reserve (Estonia). We thank Poul T. Sørensen and Tiina Tosens for their technical assistance.

Edited by: A. V. Eliseev

\section{References}

Allison, S. D., Lu, Y., Weihe, C., Goulden, M. L., Martiny, A. C., Treseder, K. K., and Martiny, J. B. H.: Microbial abundance and composition influence litter decomposition response to environmental change, Ecology, 94, 714-725, 2013.

Berg, B. and Laskowski, R.: Nitrogen dynamics in decomposing litter, Adv. Ecol. Res., 38, 157-183, 2005.

Berg, B. and McClaugherty, C.: Initial litter chemical composition, in: Plant Litter - Decomposition, Humus Formation, Carbon Sequestration, 2nd Edn., edited by: Berg, B. and McClaugherty, C., Springer-Verlag, Berlin, Heidelberg, 53-84, 2008.

Berg, B. and McClaugherty, C.: Climatic environment, in: Plant Litter - Decomposition, Humus Formation, Carbon Sequestration, Third Edition Edn., edited by: Berg, B. and McClaugherty, C., Springer, Heidelberg, New York, Dordrecht, London, 143-170, 2014a.

Berg, B. and McClaugherty, C.: Decomposition as a process: some main features, in: Plant Litter - Decomposition, Humus Formation, Carbon Sequestration, Third Edition Edn., edited by: Berg, B. and McClaugherty, C., Springer, Heidelberg, New York, Dordrecht, London, 11-34, 2014b.

Berg, B., Berg, M. P., Bottner, P., Box, E., Breymeyer, A., Deanta, R. C., Couteaux, M., Escudero, A., Gallardo, A., Kratz, W., Madeira, M., Malkonen, E., Mcclaugherty, C., Meentemeyer, V., Muñoz, F., Piussi, P., Remacle, J., and Desanto, A. V.: Litter mass-loss rates in pine forests of Europe and eastern UnitedStates - some relationships with climate and litter quality, Biogeochemistry, 20, 127-159, doi:10.1007/Bf00000785, 1993.

Bocock, K. L. and Gilbert, O. J. W.: The disappearance of leaf litter under different woodland conditions, Plant Soil, 9, 179-185, doi:10.1007/BF01398924, 1957.

Bonan, G. B., Hartman, M. D., Parton, W. J., and Wieder, W. R.: Evaluating litter decomposition in earth system models with long-term litterbag experiments: an example using the Community Land Model version 4 (CLM4), Glob. Change Biol., 19, 957-974, doi:10.1111/Gcb.12031, 2013.
Bradford, M. A., Berg, B., Maynard, D. S., Wieder, W. R., and Wood, S. A.: Understanding the dominant controls on litter decomposition, J. Ecol., 104, 229-238, doi:10.1111/13652745.12507, 2016.

Carter, M. S., Larsen, K. S., Emmett, B., Estiarte, M., Field, C., Leith, I. D., Lund, M., Meijide, A., Mills, R. T. E., Niinemets, Ü., Peñuelas, J., Portillo-Estrada, M., Schmidt, I. K., Selsted, M. B., Sheppard, L. J., Sowerby, A., Tietema, A., and Beier, C.: Synthesizing greenhouse gas fluxes across nine European peatlands and shrublands - responses to climatic and environmental changes, Biogeosciences, 9, 3739-3755, doi:10.5194/bg-93739-2012, 2012.

Cornelissen, J. H. C.: An experimental comparison of leaf decomposition rates in a wide range of temperate plant species and types, J. Ecol., 84, 573-582, doi:10.2307/2261479, 1996.

Cornelissen, J. H. C. and Thompson, K.: Functional leaf attributes predict litter decomposition rate in herbaceous plants, New Phytol., 135, 109-114, doi:10.1046/j.1469-8137.1997.00628.x, 1997.

Cotrufo, M. F., Soong, J. L., Horton, A. J., Campbell, E. E., Haddix, M. L., Wall, D. H., and Parton, A. J.: Formation of soil organic matter via biochemical and physical pathways of litter mass loss, Nat. Geosci., 8, 776-779, doi:10.1038/NGEO2520, 2015.

Dighton, J.: Nutrient cycling by saprotrophic fungi in terrestrial habitats, in: Environmental and Microbial Relationships, 2nd Edn., edited by: Esser, K., The Mycota, Springer-Verlag, Berlin, Heidelberg, 287-300, 2007.

Feng, Y. S.: K-model - A continuous model of soil organic carbon dynamics: Theory, Soil Sci., 174, 482-493, doi:10.1097/SS.0b013e3181bb0f80, 2009.

Gallardo, A. and Merino, J.: Leaf decomposition in two Mediterranean ecosystems of Southwest Spain - influence of substrate quality, Ecology, 74, 152-161, doi:10.2307/1939510, 1993.

Jacob, D., Petersen, J., Eggert, B., Alias, A., Christensen, O. B., Bouwer, L. M., Braun, A., Colette, A., Deque, M., Georgievski, G., Georgopoulou, E., Gobiet, A., Menut, L., Nikulin, G., Haensler, A., Hempelmann, N., Jones, C., Keuler, K., Kovats, S., Kroner, N., Kotlarski, S., Kriegsmann, A., Martin, E., van Meijgaard, E., Moseley, C., Pfeifer, S., Preuschmann, S., Radermacher, C., Radtke, K., Rechid, D., Rounsevell, M., Samuelsson, P., Somot, S., Soussana, J. F., Teichmann, C., Valentini, R., Vautard, R., Weber, B., and Yiou, P.: EUROCORDEX: new high-resolution climate change projections for European impact research, Reg. Environ. Change, 14, 563-578, doi:10.1007/s10113-013-0499-2, 2014.

Johansson, M. B., Berg, B., and Meentemeyer, V.: Litter mass-loss rates in late stages of decomposition in a climatic transect of pine forests - long-term decomposition in a Scots pine forest. IX., Can. J. Botany, 73, 1509-1521, 1995.

Jones, S. K., Famulari, D., Di Marco, C. F., Nemitz, E., Skiba, U. M., Rees, R. M., and Sutton, M. A.: Nitrous oxide emissions from managed grassland: a comparison of eddy covariance and static chamber measurements, Atmos. Meas. Tech., 4, 2179 2194, doi:10.5194/amt-4-2179-2011, 2011.

Kirschbaum, M. U. F.: Will changes in soil organic carbon act as a positive or negative feedback on global warming?, Biogeochemistry, 48, 21-51, doi:10.1023/A:1006238902976, 2000.

Korhonen, J. F. J., Pihlatie, M., Pumpanen, J., Aaltonen, H., Hari, P., Levula, J., Kieloaho, A.-J., Nikinmaa, E., Vesala, T., and Ilves- 
niemi, H.: Nitrogen balance of a boreal Scots pine forest, Biogeosciences, 10, 1083-1095, doi:10.5194/bg-10-1083-2013, 2013.

Liski, J., Nissinen, A., Erhard, M., and Taskinen, O.: Climatic effects on litter decomposition from arctic tundra to tropical rainforest, Glob. Change Biol., 9, 575-584, doi:10.1046/j.13652486.2003.00605.x, 2003.

Liski, J., Palosuo, T., Peltoniemi, M., and Sievanen, R.: Carbon and decomposition model Yasso for forest soils, Ecol. Model., 189, 168-182, doi:10.1016/j.ecolmodel.2005.03.005, 2005.

Liu, J. X., Fang, X., Deng, Q., Han, T. F., Huang, W. J., and Li, Y. $\mathrm{Y}$.: $\mathrm{CO}_{2}$ enrichment and $\mathrm{N}$ addition increase nutrient loss from decomposing leaf litter in subtropical model forest ecosystems, Sci. Rep.-UK, 5, 7952, doi:10.1038/Srep07952, 2015.

Machon, A., Horváth, L., Weidinger, T., Grosz, B., Moring, A., and Fuhrer, E.: Measurement and modeling of $\mathrm{N}$ balance between atmosphere and biosphere over a grazed grassland (Bugacpuszta) in Hungary, Water Air Soil Poll., 226, 27, doi:10.1007/S11270014-2271-8, 2015.

Mansfield, S. D. and Bärlocher, F.: Determination of soluble carbohydrates, in: Methods to Study Litter Decomposition. A Practical Guide, 1 Edn., edited by: Graça, M. A. S., Bärlocher, F., and Gessner, M. O., Springer, the Netherlands, 85-90, 2005.

Niinemets, Ü. and Tamm, Ü.: Species differences in timing of leaf fall and foliage chemistry modify nutrient resorption efficiency in deciduous temperate forest stands, Tree Physiol., 25, 10011014, 2005.

Olson, J. S.: Energy storage and the balance of producers and decomposers in ecological systems, Ecology, 44, 322-331, 1963.

Ormeño, E., Céspedes, B., Sánchez, I. A., Velasco-García, A., Moreno, J. M., Fernández, C., and Baldy, V.: The relationship between terpenes and flammability of leaf litter, Forest Ecol. Manag., 257, 471-482, doi:10.1016/j.foreco.2008.09.019, 2009.

Owen, S. M., Leaver, D. S., Bealey, W. J., Wilson, R., Reis, S., and Sutton, M.: A new database for time-series monitoring data: the NitroEurope approach, Iforest, 4, 226-232, doi:10.3832/Ifor0595-004, 2011.

Pérez-Suárez, M., Arredondo-Moreno, J. T., and Huber-Sannwald, E.: Early stage of single and mixed leaf-litter decomposition in semiarid forest pine-oak: the role of rainfall and microsite, Biogeochemistry, 108, 245-258, doi:10.1007/s10533-011-9594y, 2012.
Pilegaard, K., Ibrom, A., Courtney, M. S., Hummelshoj, P., and Jensen, N. O.: Increasing net $\mathrm{CO}_{2}$ uptake by a Danish beech forest during the period from 1996 to 2009, Agr. Forest Meteorol., 151, 934-946, doi:10.1016/j.agrformet.2011.02.013, 2011.

Pinheiro, J., Bates, D., DebRoy, S., Sarkar, D., and R Core Team: nlme: linear and nonlinear mixed effects models, $\mathrm{R}$ package version 3.1-121, 2013.

Portillo-Estrada, M., Korhonen, J. F. J., Pihlatie, M., Pumpanen, J., Frumau, A. K. F., Morillas, L., Tosens, T., and Niinemets, $\ddot{U}$.: Inter- and intra-annual variations in canopy fine litterfall and carbon and nitrogen inputs to the forest floor in two European coniferous forests, Ann. Forest Sci., 70, 367-379, doi:10.1007/s13595-013-0273-0, 2013.

Portillo-Estrada, M., Copolovici, L., and Niinemets, Ü.: Bias in leaf dry mass estimation after oven-drying isoprenoid-storing leaves, Trees, 29, 1805-1816, doi:10.1007/s00468-015-1262-8, 2015.

Portsmuth, A., Niinemets, Ü., Truus, L., and Pensa, M.: Biomass allocation and growth rates in Pinus sylvestris are interactively modified by nitrogen and phosphorus availabilities and by tree size and age, Can. J. Forest Res., 35, 2346-2359, doi:10.1139/X05-155, 2005.

Vestgarden, L. S.: Carbon and nitrogen turnover in the early stage of Scots pine (Pinus sylvestris L.) needle litter decomposition: effects of internal and external nitrogen, Soil Biol. Biochem., 33, 465-474, doi:10.1016/S0038-0717(00)00187-5, 2001.

Wright, W. and Illius, A. W.: A comparative-study of the fracture properties of 5 grasses, Funct. Ecol., 9, 269-278, doi:10.2307/2390573, 1995.

Zhang, L., Zhang, Y. J., Zou, J. W., and Siemann, E.: Decomposition of Phragmites australis litter retarded by invasive Solidago canadensis in mixtures: an antagonistic non-additive effect, Sci. Rep.-UK, 4, 5488, doi:10.1038/Srep05488, 2014.

Zhang, C. F., Trofymow, J. A., Jamieson, R. C., Meng, F. R., Gordon, R., and Bourque, C. P. A.: Litter decomposition and nitrogen mineralization from an annual to a monthly model, Ecol. Model., 221, 1944-1953, doi:10.1016/j.ecolmodel.2010.04.015, 2010.

Zhang, D. Q., Hui, D. F., Luo, Y. Q., and Zhou, G. Y.: Rates of litter decomposition in terrestrial ecosystems: global patterns and controlling factors, J. Plant Ecol., 1, 85-93, doi:10.1093/jpe/rtn002, 2008. 